\title{
Depiction of Adolescents Smoking Behaviour in Urban and Suburban
}

\author{
Toghur Arifani Lubis ${ }^{1}, \underline{R}$. Kintoko Rochadi ${ }^{2}$ \\ 1,2Department of Health Promotion and Behavioral Science, Universitas Sumatera Utara, Medan, Indonesia \\ Email: toghurarifani@yahoo.com
}

\begin{abstract}
:
Smoking is a fatal issue that has not yet been resolved and spread even among adolescents particularly in Indonesia. This study aim to depict the adolescents smoking behavior in SMPN three Medan or urban areas and MTS Amin Darussalam Deli Serdang or suburban areas. This cross sectional study conducted on October. Data were collected using questionnaires toward students from both school. Results shows majority respondent in urban have good knowledge, negative attitude toward cigarette and non-smokers but interested in smoking, majority of former smokers in urban firstly tried smoking during sixth grade elementary because of peer influence, smoking occasionally, ever smoked one to five cigarettes per day, quit smoking because of selfawareness and still have interest in smoking. Furthermore, majority respondent in suburban have bad bad knowledge, negative attitude toward cigarette, smoker, firstly tried smoking during sixth grade elementry because of peer influence, smoking occasionally, ever smoked one to five cigarettes per day and have no intention to quit smoking, majority of former smokers quit smoking because of caught by parent or teacher and still have interest in smoking. In conclusion, there is difference of smoking behavior between urban and suburban, the depiction of smoking behavior in suburban is worse than in urban because it has higher number of smokers, poorly dominant of knowledge and have no intention to quit smoking.
\end{abstract}

Keywords:

smoking; adolescence; urban; suburban

\section{Introduction}

Cigarettes contain nicotine, which is able to decrease tension during its existence in the body but after it comes to an end, anxiety or tension are going to arise so that the smoker will encounter addiction from it [1]. Beside nicotine, there are 4000 chemical compounds inside cigarettes that might affect the body and cause health problems such as diminution of oxygen in the blood, addiction, cancer (Indonesian Health Ministry, 2012) and insomnia (Kairupan, 2016).

The dangers of smoking are experienced not only to the smokers but also people around them, other people's cigarette smoke can cause around 603.000 premature death in 2004 in which 166.000 because of lower respiratory tract 's infection and 1100 because of asthma for the children. To the tune of 35800 because of asthma, 21.000 because of lung cancer and 379.000 because of ischemic heart disease (IHD) for the adults. Of all deaths caused by AROL, 28\% happening to children and 47\% to women (World Health Organization, 2010).

Realizing how broad the burden caused by smoking, WHO by way of FCTC has expanded 6 strategies to degrade and deprive smoking behavior named MPOWER, many nations have adjusted this then succeed to lower smokers proportion (World Health Organization, 2013). Whereas in Indonesia itself, according to reference (World Health Organization, 2012) smokers prevalence rank rises to the second biggest in the world. The 
result in basic health research in Indonesia indicates that smoking proportion in Indonesia aged $\geq 15$ years old continues to increase from $34,2 \%$ (Indonesian Health Ministry, 2007) to $34,7 \%$ (Indonesian Health Ministry, 2010) and rise again to 36,3\% (Indonesian Health Ministry, 2013).

Survey result of reference (World Health Organization, 2015) represents around $33,9 \%$ men who are smoker in which $2,5 \%$ aged $13-15$ years old. Smokers in Indonesia began their smoking behavior since earl age that is between $15-19$ years old and $5-9$ years old, rationally, the average age to start smoking for the first try is 17,6 years old. Those who begin smoking not only in $15-19$ years old but also $5-9$ years old are always more in men than women who live in the urban (Indonesian Health Ministry, 2010). The recent data points $31,8 \%$ men and 0,55 women aged $10-24$ years old are smokers in Indonesia and North Sumatera is the fourth position with the highest number of smokers aged $>10$ years old (Indonesian Health Ministry, 2013).

\section{Research Method}

A descriptive analytic research had been applied to 84 junior high school students aged 13 - 15 years old in two schools with two disparate environment those are MTS Amin Darussalam located in Terusan street ,Bandar Setia, Percut Seituan sub-districts Deli Serdang district, Sumatera Utara Region by the total 41 respondents (27 males and 4 females). Another school is SMPN 3 located in Pelajar street Medan Kota sub-districts, Medan, sumatera utara region with overall 43 respondents ( 29 males and 4 females).

Data collected by questionnaire filled with 4 sub questions covering respondent's identity, knowledge, behavior and action. Before answering the questions, respondents had been explained all about the questions paper that must be responded and described that their information will be keep confidential although by the time the respondents replied for the questionnaire, most of them still asked to make sure that the information would not be complained to their teachers even respondents keep glancing to the teachers in that time.

\section{Discussion}

\subsection{Results}

The results of this study are presented in 8 tables containing respondent characteristics, smoking status based on respondent characteristics, smoking activity ever undertaken, smoking status based on smoking activities ever undertaken, smoking interest (questioned to former smokers and nonsmokers), intention of smokers to quit smoking, reasons of former smokers to quit smoking and Chisquare test result.

\section{a. Respondents Characteristics}

Tab. I shows respondents in SMP (urban) were male by $90,7 \%$ and female $(9,3 \%)$, grade $7(30,2 \%)$, grade $8(34,9 \%)$, grade $9(34,9 \%)$, smoker $(0 \%)$, former smoker $(4,7 \%)$, nonsmoker $(95,3 \%)$, had good knowledge $(69,8 \%)$, bad knowledge $(30,2 \%)$, had negative attitude $(90,7 \%)$ and positive attitude toward smoking $(9,3 \%)$.

MTS (suburban) shows male (90,2\%); female (9,8\%), grade $7(39 \%)$; grade $8(31,7 \%)$; grade $9(29,3 \%)$, smoker (61\%); former smoker (19,5\%); non-smoker(19,5\%), had good knowledge (39\%), bad knowledge (61\%), had negative attitude $(82,9 \%)$ and positive attitude toward smoking $(17,1 \%)$. 
Britain International of Humanties and Social Sciences (BIoHS) Journal

ISSN: 2685-3868(Online), 2685-1989(Print)

Vol. 2, No. 1, February 2020, Page: 238-246

b. Smoking Status Based on Respondents Characteristics

Table 1. Respondent General Characteristic in SMPN 3 (Urban) and Mts Amin D (Suburban)

\begin{tabular}{|c|c|c|c|c|}
\hline \multirow{2}{*}{ Variables } & \multicolumn{2}{|c|}{ SMPN 3 (Urban) } & \multicolumn{2}{c|}{ MTS Amin (Suburban) } \\
\cline { 2 - 5 } & $\mathrm{n}$ & $\%$ & $\mathrm{n}$ & $\%$ \\
\hline Sex & & & & \\
\hline Male & 39 & 90,7 & 37 & 90,2 \\
\hline Female & 4 & 9,3 & 4 & 9,8 \\
\hline Grade & & & & \\
\hline Grade 7 & 13 & 30,2 & 16 & 39 \\
\hline Grade 8 & 15 & 34,9 & 13 & 31,7 \\
\hline Grade 9 & 15 & 34,9 & 12 & 29,3 \\
\hline Smoking status & & & & \\
\hline Smoker & 0 & 0 & 25 & 61 \\
\hline Former smoker & 2 & 4,7 & 8 & 19,5 \\
\hline Non-smoker & 41 & 95,3 & 8 & 19,5 \\
\hline Knowledge & & & & \\
\hline Good & 30 & 69,8 & 16 & 39 \\
\hline Bad & 13 & 30,2 & 25 & 61 \\
\hline $\begin{array}{c}\text { Attitude toward } \\
\text { cigarettes }\end{array}$ & & & & \\
\hline Positive & 4 & 9,3 & 7 & 17,1 \\
\hline Negative & 39 & 90,7 & 34 & 82,9 \\
\hline Total & $\mathbf{4 3}$ & $\mathbf{1 0 0}$ & $\mathbf{4 1}$ & $\mathbf{1 0 0}$ \\
\hline
\end{tabular}

Table 2. Smoking Status Based On Respondent Characteristics in SMPN 3 (Urban) and Mts Amin (Suburban)

\begin{tabular}{|c|c|c|c|c|c|c|c|c|c|c|c|c|c|c|c|c|}
\hline \multirow{4}{*}{ Variables } & \multicolumn{16}{|c|}{ Smoking status } \\
\hline & \multicolumn{6}{|c|}{ SMPN 3 (Urban) } & \multirow{2}{*}{\multicolumn{2}{|c|}{ Total }} & \multicolumn{6}{|c|}{ MTS Amin (Suburban) } & \multirow{2}{*}{\multicolumn{2}{|c|}{ Total }} \\
\hline & \multicolumn{2}{|c|}{ Smoker } & \multicolumn{2}{|c|}{$\begin{array}{l}\text { Former } \\
\text { Smoker }\end{array}$} & \multicolumn{2}{|c|}{$\begin{array}{l}\text { Non } \\
\text { Smoker }\end{array}$} & & & \multicolumn{2}{|c|}{ Smoker } & \multicolumn{2}{|c|}{$\begin{array}{l}\text { Former } \\
\text { Smoker }\end{array}$} & \multicolumn{2}{|c|}{$\begin{array}{l}\text { Non } \\
\text { Smoker }\end{array}$} & & \\
\hline & $\mathrm{n}$ & $\%$ & $\mathrm{n}$ & $\%$ & $\mathrm{n}$ & $\%$ & $\mathrm{n}$ & $\%$ & $\mathrm{n}$ & $\%$ & $\mathrm{n}$ & $\%$ & $\mathrm{n}$ & $\%$ & $\mathbf{n}$ & $\%$ \\
\hline \multicolumn{17}{|l|}{ Sex } \\
\hline Male & 0 & 0 & 2 & 4,7 & 37 & 86 & 39 & 90,7 & 24 & 58,5 & 7 & 17,1 & 6 & 14,6 & 37 & 90,2 \\
\hline Female & 0 & 0 & 0 & 0 & 4 & 9,3 & 4 & 9,3 & 1 & 2,5 & 1 & 2,4 & 2 & 4,9 & 4 & 9,8 \\
\hline \multicolumn{17}{|l|}{ Grade level } \\
\hline Grade 7 & 0 & 0 & 0 & 0 & 13 & 30,2 & 13 & 30,2 & 8 & 19,5 & 2 & 4,9 & 6 & 14,6 & 16 & 39 \\
\hline Grade 8 & 0 & 0 & 0 & 0 & 15 & 34,9 & 15 & 34,9 & 9 & 21,9 & 2 & 4,9 & 2 & 4,9 & 13 & 31,7 \\
\hline Grade 9 & 0 & 0 & 2 & 4,7 & 13 & 30,2 & 15 & 34,9 & 8 & 19,5 & 4 & 9,8 & 0 & 0 & 12 & 29,3 \\
\hline \multicolumn{17}{|l|}{ Knowledge } \\
\hline Good & 0 & 0 & 2 & 4,7 & 28 & 65,1 & 30 & 69,8 & 0 & 0 & 8 & 19,5 & 8 & 19,5 & 16 & 39 \\
\hline $\mathrm{Bad}$ & 0 & 0 & 0 & 0 & 13 & 30,2 & 13 & 30,2 & 25 & 61 & 0 & 0 & 0 & 0 & 25 & 61 \\
\hline \multicolumn{17}{|l|}{ Attitude } \\
\hline Positive & 0 & 0 & 0 & 0 & 4 & 9,3 & 4 & 9,3 & 5 & 12,2 & 2 & 4,9 & 0 & 0 & 7 & 17,1 \\
\hline Negative & 0 & 0 & 2 & 4,7 & 37 & 86 & 39 & 90,7 & 20 & 48,8 & 6 & 14,6 & 8 & 19,5 & 34 & 82,9 \\
\hline Total & 0 & 0 & 2 & 5 & 41 & 95 & 43 & 100 & 25 & 61 & 8 & 19,5 & 8 & 19,5 & 41 & 100 \\
\hline
\end{tabular}

Table 2 shows in SMP (urban) that all former smokers were male, grade 9, had good knowledge and had negative attitude toward smoking. While non-smoker characteristics were male (86\%); female (9,3\%), grade 7 (30,2\%); grade 8 (34,9\%); grade 9 (30,2\%), had good knowledge $(65,1 \%)$, bad knowledge $(30,2 \%)$, had negative attitude $(86 \%)$ and positive attitude 
toward smoking $(9,3 \%)$.

MTS (suburban) shows smokers characteristics were male (58,5\%); female (2,5\%), grade 7 (19,5\%); grade 8 (21,9\%); grade 9 (19,5\%), had good knowledge $(0 \%)$, bad knowledge $(61 \%)$, had negative attitude $(48,8 \%)$ and positive attitude toward smoking $(12,2 \%)$.

Former smokers characteristics were male $(17,1 \%)$; female $(2,4 \%)$, grade $7(4,9 \%)$; grade 8 (4,9\%); grade 9 (9,8\%), had good knowledge (19,5\%), bad knowledge $(0 \%)$, had negative attitude $(19,5 \%)$ and positive attitude toward smoking $(0 \%)$.

Non-smokers characteristics were male $(14,6 \%)$; female $(4,9 \%)$, grade $7(14,6 \%)$; grade 8 (4,9\%); grade $9(0 \%)$, had good knowledge (19,5\%), bad knowledge $(0 \%)$, had negative attitude $(19,5 \%)$ and positive attitude toward smoking $(0 \%)$.

\section{c. Smoking Activities Ever Undertaken}

Table 3. Smoking Activities Ever Undertaken By Respondent in SMPN 3 (Urban) and Mts Amin (Suburban)

\begin{tabular}{|c|l|l|l|l|}
\hline \multirow{2}{*}{ Variables } & \multicolumn{2}{|l|}{ SMPN 3 (Urban) } & \multicolumn{2}{l|}{ MTS Amin (Suburban) } \\
\cline { 2 - 5 } & $\mathrm{n}$ & $\%$ & $\mathrm{n}$ & $\%$ \\
\hline Firstly tried to smoke & & & & \\
\hline Grade 4 elementary & 0 & 0 & 8 & 24,2 \\
\hline Grade 5 elementary & 0 & 0 & 3 & 9,1 \\
\hline Grade 6 elementary & 1 & 50 & 17 & 51,5 \\
\hline Grade 1 junior high & 1 & 50 & 2 & 6,1 \\
\hline Grade 2 junior high & 0 & 0 & 2 & 6,1 \\
\hline Grade 3 junior high & 0 & 0 & 1 & 3 \\
\hline $\begin{array}{l}\text { Number of cigarettes } \\
\text { ever smoked }\end{array}$ & & & & \\
\hline 1-5 cigarettes /day & 2 & 100 & 31 & 93,9 \\
\hline 6-10 cigarettes/day & 0 & 0 & 2 & 6,1 \\
\hline Smoking frequency & & & & \\
\hline Daily & 0 & 0 & 2 & 6,1 \\
\hline Occasionally & 2 & 100 & 31 & 93,9 \\
\hline Smoking premises & & & & \\
\hline Parent who smoke & 0 & 0 & 2 & 6,1 \\
\hline Fellow up & 2 & 100 & 29 & 87,8 \\
\hline Advertisement & 0 & 0 & 2 & 6,1 \\
\hline $\begin{array}{l}\text { Not smoking under no } \\
\text { smoking sign }\end{array}$ & & & & \\
\hline Yes & 2 & 100 & 16 & 48,5 \\
\hline No & 0 & 0 & 17 & 51,5 \\
\hline Total & $\mathbf{2}$ & $\mathbf{1 0 0}$ & $\mathbf{3 3}$ & $\mathbf{1 0 0}$ \\
\hline
\end{tabular}

Table 3 shows that former smokers in SMP (urban) firstly tried to smoke during grade 6 elementary (50\%) and grade 1 junior high (50\%), ever smoke 1-5 cigarettes/day (100\%), smoking occasionally $(100 \%)$, fellow up smokers $(100 \%)$ and not smoking under no smoking $\operatorname{sign}(100 \%)$.

MTS (suburban) shows respondents who ever smoked, firstly tried to smoke during 
grade 4 elementary $(24,2 \%)$, grade 5 elementary $(9,1 \%)$, grade 6 elementary $(51,5 \%)$, grade 1 junior high (6,1\%), grade 2 junior high $(6,1 \%)$ and grade 3 junior high $(3 \%)$. Ever smoked 1-5 cigarettes/day (93,9\%) and 6-10 cigarettes/day (6,1\%). Smoking daily (6,1\%) and smoking occasionally $(93,9 \%)$. Smoking because parent who smoke $(6,1 \%)$, fellow-up $(87,8 \%)$ and advertisement (6,1\%). Do not smoking under no smoking sign (48,5\%) and still smoking under no smoking sign $(51,5 \%)$.

\section{d. Smoking Status Based on Smoking Activities Ever Undertaken}

Table 4. Smoking Status Based on Smoking Activities Ever Undertaken in SMPN 3 (Urban) and Mts Amin (Suburban)

\begin{tabular}{|c|c|c|c|c|c|c|c|c|c|c|c|c|}
\hline \multirow{4}{*}{ Variables } & \multicolumn{12}{|c|}{ Smoking status } \\
\hline & \multicolumn{4}{|c|}{ SMPN 3 (Urban) } & \multirow{2}{*}{\multicolumn{2}{|c|}{ Total }} & \multicolumn{4}{|c|}{$\begin{array}{l}\text { MTS Amin } \\
\text { (Suburban) }\end{array}$} & \multirow{2}{*}{\multicolumn{2}{|c|}{ Total }} \\
\hline & \multicolumn{2}{|c|}{ Smoker } & \multicolumn{2}{|c|}{$\begin{array}{l}\text { Former } \\
\text { Smoker }\end{array}$} & & & \multicolumn{2}{|c|}{ Smoker } & \multicolumn{2}{|c|}{$\begin{array}{l}\text { Former } \\
\text { Smoker }\end{array}$} & & \\
\hline & $\mathrm{n}$ & $\%$ & $\mathrm{n}$ & $\%$ & $\mathrm{n}$ & $\%$ & $\mathrm{n}$ & $\%$ & $\mathrm{n}$ & $\%$ & $\mathrm{n}$ & $\%$ \\
\hline \multicolumn{13}{|l|}{ Firstly tried to smoke } \\
\hline Grade 4 elementary & 0 & 0 & 0 & 0 & 0 & 0 & 6 & 18,1 & 2 & 6,1 & 8 & 24,2 \\
\hline Grade 5 elementary & 0 & 0 & 0 & 0 & 0 & 0 & 3 & 9,1 & 0 & 0 & 3 & 9,1 \\
\hline Grade 6 elementary & 0 & 0 & 1 & 50 & 1 & 50 & 13 & 39,4 & 4 & 12,1 & 17 & 51,5 \\
\hline Grade 1 junior high & 0 & 0 & 1 & 50 & 1 & 50 & 2 & 6,1 & 0 & 0 & 2 & 6,1 \\
\hline Grade 2 junior high & 0 & 0 & 0 & 0 & 0 & 0 & 1 & 3 & 1 & 3 & 2 & 6,1 \\
\hline Grade 3 junior high & 0 & 0 & 0 & 0 & 0 & 0 & 0 & 0 & 1 & 3 & 1 & 3 \\
\hline \multicolumn{13}{|l|}{$\begin{array}{l}\text { Number of cigarettes } \\
\text { ever smoked }\end{array}$} \\
\hline 1-5 cigarettes per day & 0 & 0 & 2 & 100 & 2 & 100 & 23 & 69,7 & 8 & 24,2 & 31 & 93,9 \\
\hline 6-10 cigarettes per day & 0 & 0 & 0 & 0 & 0 & 0 & 2 & 6,1 & 0 & 0 & 2 & 6,1 \\
\hline \multicolumn{13}{|l|}{ Smoking frequency } \\
\hline Daily & 0 & 0 & 0 & 0 & 0 & 0 & 2 & 6,1 & 0 & 0 & 2 & 6,1 \\
\hline Occasionally & 0 & 0 & 2 & 100 & 2 & 100 & 23 & 69,7 & 8 & 24,2 & 31 & 93,9 \\
\hline \multicolumn{13}{|l|}{ Smoking premises } \\
\hline Parent who smoke & 0 & 0 & 0 & 0 & 0 & 0 & 2 & 6,1 & 0 & 0 & 2 & 6,1 \\
\hline Fellow up & 0 & 0 & 2 & 100 & 2 & 100 & 23 & 69,7 & 6 & 18,1 & 29 & 87,8 \\
\hline Advertisement & 0 & 0 & 0 & 0 & 0 & 0 & 0 & 0 & 2 & 6,1 & 2 & 6,1 \\
\hline \multicolumn{13}{|l|}{$\begin{array}{l}\text { Not smoking under the } \\
\text { "no smoking" sign }\end{array}$} \\
\hline Yes & 0 & 0 & 2 & 100 & 2 & 100 & 8 & 24,2 & 8 & 24,2 & 16 & 48,5 \\
\hline No & 0 & 0 & 0 & 0 & 0 & 0 & 17 & 51,5 & 0 & 0 & 17 & 51,5 \\
\hline Total & 0 & 0 & 2 & 100 & 2 & 100 & 25 & 75,8 & 8 & 24,2 & 33 & 100 \\
\hline
\end{tabular}

Table 4 shows the results in SMP (urban) is as same as in table 3 because $0 \%$ smokers so all ao the activities came from former smokers answer. While in MTS (suburban) shows smokers firstly tried to smoke during grade during grade 4 elementary $(18,1 \%)$, grade 5 elementary $(9,1 \%)$, grade 6 elementary $(39,4 \%)$, grade 1 junior high $(6,1 \%)$, grade 2 junior high $(3 \%)$ and grade 3 junior high (0\%). Ever smoked 1-5 cigarettes/day (69,7\%) and 6-10 cigarettes/day (6,1\%). Smoking daily $(6,1 \%)$ and smoking occasionally (69,7\%). Smoking because parent who smoke $(6,1 \%)$, fellow-up $(69,7 \%)$ and advertisement $(0 \%)$. Do not smoking under no smoking sign $(24,2 \%)$ and still smoking under no smoking sign $(51,5 \%)$.

On the other hand former smokers firstly tried to smoke during grade 4 elementary $(6,1 \%)$, grade 5 elementary $(0 \%)$, grade 6 elementary $(12,1 \%)$, grade 1 junior high $(0 \%)$, grade 2 junior high $(3 \%)$ and grade 3 junior high (3\%). Ever smoked $1-5$ cigarettes/day $(24,2 \%)$ and 6-10 cigarettes/day (0\%). Smoking daily $(0 \%)$ and smoking occasionally $(24,2 \%)$. Smoking because parent who smoke $(0 \%)$, fellow-up $(18,1 \%)$ and advertisement $(6,1 \%)$. Do not 
smoking under no smoking sign $(24,2 \%)$ and still smoking under no smoking sign $(0 \%)$.

\section{e. Former smokers and Non-smokers Interest in Smoking}

Based on table 5 in SMPN 3 found that $95.3 \%$ of respondents were interested and $4.7 \%$ were not interested in smoking, while in MTS 75\% were interested and 25\% were not interested in smoking.

Table 5. Former Smoker and Non-Smoker of Interest in Smoking in SMPN 3 (Urban) and Mts Amin (Suburban)

\begin{tabular}{|c|l|l|l|l|}
\hline \multirow{2}{*}{ Variables } & \multicolumn{2}{|l|}{ SMPN 3 (Urban) } & \multicolumn{2}{l|}{ MTS Amin (Suburban) } \\
\cline { 2 - 5 } & $\mathrm{n}$ & $\%$ & $\mathrm{n}$ & $\%$ \\
\hline Interesting in smoking & & & & \\
\hline Yes & 41 & 95,3 & 12 & 75 \\
\hline No & 2 & 4,7 & 4 & 25 \\
\hline Total & $\mathbf{4 3}$ & $\mathbf{1 0 0}$ & $\mathbf{1 6}$ & $\mathbf{1 0 0}$ \\
\hline
\end{tabular}

\section{f. Smoker Intention to Quit Smoking}

Table 6. Smoker Intention to Quit Smoking in Mts Amin Darussalam (Suburban)

\begin{tabular}{|c|l|l|l|l|}
\hline \multirow{2}{*}{ Variables } & \multicolumn{2}{|l|}{ SMPN 3 (Urban) } & \multicolumn{2}{l|}{ MTS Amin (Suburban) } \\
\cline { 2 - 5 } & $\mathrm{n}$ & $\%$ & $\mathrm{n}$ & $\%$ \\
\hline Intend to quit smoking & & & & \\
\hline Yes & 0 & 0 & 12 & 48 \\
\hline No & 0 & 0 & 13 & 52 \\
\hline Total & $\mathbf{0}$ & $\mathbf{0}$ & $\mathbf{2 5}$ & $\mathbf{1 0 0}$ \\
\hline
\end{tabular}

Table 6 shows $48 \%$ of smokers in MTS (suburban) have intentions and $52 \%$ have no intention to quit smoking.

\section{g. Former Smokers Reason for Quitting Smoking}

Table 7. Former Smoker Reason for Quitting Smoking in SMPN 3 (Urban) and Mts Amin (Suburban)

\begin{tabular}{|l|l|l|l|l|}
\hline \multirow{2}{*}{ Variables } & \multicolumn{2}{|l|}{ SMPN 3 (Urban) } & \multicolumn{2}{l|}{ MTS Amin (Suburban) } \\
\cline { 2 - 5 } & $\mathrm{n}$ & $\%$ & $\mathrm{n}$ & $\%$ \\
\hline The reason for quitting smoking & & & & \\
\hline Caught & 1 & 50 & 7 & 87,5 \\
\hline Self-awareness & 1 & 50 & 0 & 0 \\
\hline No more friends with smoker friends & 0 & 0 & 1 & 12,5 \\
\hline Total & $\mathbf{2}$ & $\mathbf{1 0 0}$ & $\mathbf{8}$ & $\mathbf{1 0 0}$ \\
\hline
\end{tabular}

Table 7 shows $50 \%$ of former smokers in SMP (urban) quitted smoking because of self-awareness and 50\% due to caught / fear of being scolded, whereas in MTS (suburban) $87.5 \%$ quitted smoking due to caught and $12.5 \%$ not smoking anymore because no more friends with smoker friends.

\section{h. Smoking Prevention Behaviour Difference between SMP (urban) and MTS (suburban)}

Table 8. Difference Of Smoking Prevention Behavior between SMPN 3 (Urban) and Mts Amin (Suburban)

\begin{tabular}{|l|l|l|l|l|l|}
\hline & \multicolumn{3}{|c|}{$\begin{array}{c}\text { Smoking prevention } \\
\text { behaviour }\end{array}$} & P value \\
\hline & Good & Bad & \\
\hline & $\mathbf{n}$ & $\mathbf{\%}$ & $\mathbf{n}$ & $\mathbf{\%}$ & \\
\hline
\end{tabular}




\begin{tabular}{|l|l|l|l|l|l|l|}
\hline School (location) & SMPN 3 (urban) & 43 & 72,9 & 0 & 0 & 0,000 \\
\hline & $\begin{array}{l}\text { MTS Amin } \\
\text { Darussalam (suburban) }\end{array}$ & 16 & 27,1 & 25 & 100 & \\
\hline & Total & $\mathbf{5 9}$ & $\mathbf{1 0 0}$ & $\mathbf{2 5}$ & $\mathbf{1 0 0}$ & \\
\hline
\end{tabular}

Smoking prevention behaviour between two schools was tested with Chisquare to know if there is difference of smoking prevention behaviour between SMPN 3 Medan that located in urban area and MTS Amin Darussalam Deli Serdang that located in suburban area.

\subsection{Discussion}

The results of the study found more smokers in MTS (suburban) that could be caused by differences in the level of knowledge and attitudes of respondents from both schools. Low knowledge tends to make people have a positive attitude toward smoking behavior (Cahyo, 2012). Results in SMP (urban) showed respondents with poor knowledge by $30.2 \%$ (all nonsmokers) but 9.3\% (all former smokers) had positive attitude toward smoking, while in MTS (suburban) respondents with knowledge badly 61\% (overall respondents with poor knowledge are smokers) and had a positive attitude towards cigarettes by $17.1 \%(12.2 \%$ are smokers and $4.9 \%$ are former smokers).

Research in Makassar indicates no association of knowledge with students' smoking behavior (Rachmat, 2013). Other studies in Solo showed no correlation between knowledge ( $p$ $=0,335)$ with students' smoking behavior but there was a significant correlation between perception $(p=0,21)$ with student smoking behavior level (Nurmayunita).

Based on the 4th and 5th tables of smoking activities, the results showed in SMP (urban) former smokers respondent firstly tried to smoke during grade 6 elementary school is $50 \%$ while in MTS (suburban) even it varies from grade 4 elementary up to grade 3 junior high but in MTS half of respondents that ever smoking also start during grade 6 elementary school. This is appropriate with the research in Semarang that showed most of respondents started smoking since the age $<15$ years (Cahyo, 2012).

Based on majority results viewed from the number of cigarettes (almost of them ever smoking 1-5 cigarettes per day) and smoking frequencies (smoking occasionally) the respondents in both schools are still classified as light and medium smokers (Smet, 1994)) and when looked by the type then respondents including experimentation stage; at this stage a person has been consuming cigarettes and the number continues to increase but the person has not experienced nicotine dependence can easily to quit smoking (Leventhal, 1980).

Various reason for respondents to have cigarettes smoking, however, majority respondents in both schools admitted smoking because of friends that is 100\% (SMP) and $87.8 \%$ (MTS). It can be seen that friends who smoke have great influence on respondents' smoking behavior, this is because adolescence tend to label "friends" if they have the same belief about smoking and the more positive their friend belief toward smoking the stronger friendship label (Ragan, 2016). Other studies have shown that the influence of peers, advertising (Rachmat, 2013) and parents or brothers who smoked have a strong influence on smoking behavior of students (Cahyo, 2012).

This study showed that 100\% former smokers in SMP (urban) do not smoke in place with prohibited smoking, while in MTS (suburban) 51.5\% of smokers kept on smoking even in places with no smoking signs. 
Based on table 5 in SMPN 3 found that $95.3 \%$ of respondents were interested but in MTS 75\% were interested. A similar study conducted in eastern Java showed that $44.25 \%$ respondents had intentions of smoking that were influenced by attitudes, smoking parents, cigarette advertisements, and peer influences (Yee, 2016).

On this study, smokers were asked about their intention to quit smoking and former smokers' reason to quit smoking which is depicted in the tables below.

Almost half (48\%) of smokers have intentions and $52 \%$ have no intention to quit smoking. Results in SMP (urban) showed 50\% of former smokers quitted smoking because of self-awareness and 50\% due to caught / fear of being scolded, whereas in MTS (suburban) $87.5 \%$ quitted smoking due to caught and $12.5 \%$ not smoking anymore because no more friends with smoker friends.

Similar studies showed that desire to quit smoking is motivated by diverse motivations, for example health, financial, other influences, religious reasons and strong self-determination (Rosemary, 2013) but strong intentions to quit smoking and smoking frequency has a relationship in determining the success of quitting smoking (Rosita, 2012). The main obstacles to quit smoking were the addictive factor and living in an environment with smokers majority. (Rosemary, 2013)

The evidence showed that nicotine exposure in adolescents produces persistent changes in affect, cognition, drug-related behavior, and neurobiology. Constant change results in a prolonged abstinence syndrome characterized by negative effects, cognitive deficits, and increased reactivity to nicotine and other drugs that can reduce smoking cessation. Much of this change isn't found in nicotine exposure in adulthood which suggests that nicotine exposure during adolescence may lead to the possibility of smoking and increased smoking progression compared with adult nicotine exposure (Lydon, 2014).

\section{Conclusion}

There is difference of smoking behavior between urban and suburban, the depiction of smoking behavior in suburban is worse than in urban because it has higher number of smokers, poorly dominant of knowledge and have no intention to quit smoking. It is recommended that school as an extension of the family's hand in shaping students' behavior needs to be involved more intensively, especially in the prevention of smoking behavior in adolescents. Students need to be given counseling to increase their knowledge about the dangers of smoking and be given training to refuse smoking invitations from their friends.

\section{Acknowledgment}

We are grateful to the head of school for their assistance in this study, we also thankful to all of the participant and people who were involved in this study. 


\section{References}

Indonesian Health Ministry, Bulletin Window Data And Information Non Communicable Diseases, Jakarta: Agency for Health Research and Development, 2012.

Kairupan J.M.A., Rottie J.V., Malara R.T., Smoking Relationship With Insomnia Occurrence In Teens In Sma State 1 Remboken Minahasa District, vol. 4, no. 1. Ejournal Nursing (E-Kp), 2016, pp.1-8.

World Health Organization, Global Estimate Of The Burden Of Disease From Second-Hand Smoke, Switzerland : Who Press, 2010.

World Health Organization, Who Report On The Global Tobacco Epidemic, Luxembourg : WHO press, 2013.

World Health Organization, Global Adult Tobacco Survey: Indonesia Report 2011, Jakarta, 2012.

Indonesian Health Ministry, Basic Health Research 2007. Jakarta: Agency for Health Research and Development, 2007.

Indonesian Health Ministry, Basic Health Research 2010. Jakarta: Agency for Health Research and Development, 2010.

Indonesian Health Ministry, Basic Health Research 2013. Jakarta: Agency for Health Research and Development, 2013.

World Health Organization, Global Youth Tobacco Survey (GYTS): Indonesia Report 2014, New Delhi: WHO-SEARO, 2015.

Cahyo K., Wigati P.A., Shaluhiyah Z., Cigarettes, Marketing Patterns and Smoking Behavior Among High School Students in the City of Semarang, vol. 11, no. 1, Media of Public Health Indonesia, 2012, pp.75-84.

Rachmat, M., Thaha, R.M., Syafar, M., Smoking Behavior at Junior High School, vol. 7, no. 11, Journal of National Public Health, 2013, pp. 502-8.

Nurmayunita D., Astuti D., Werdani K.E., Relationship Between Knowledge, Exposure to Advertising Media and Perception With Smoking Level of Senior Hight School Student Behavior, Proceedings of National Seminar of Faculty of Health Sciences, ISSN 2460-4143.

Smet B., Health Psychology, Jakarta: Gramedia, 1994.

Leventhal, H., Cleary, P.D., The Smoking Problem: A Review Of The Research And Theory In Behavioral Risk Modification, vol. 88, no. 2, Psychological Bulletin, 1980, pp. 370405.

Ragan D.T., Peer beliefs and smoking in adolescence: A longitudinal social network analysis, vol. 42, no. 2, Am J Drug Alcohol Abuse, 2016, pp. 222-30.

Yee, N.L., Sunjaya, D.K., Haryadi, R.M., Factors Related to the Intention to Cigarette Smoking among Junior High School Students in Jatinangor Subdistrict, West Java, vol. 2, no. 3, AMJ, 2016, pp. 314-18.

Rosemary R., Between Motivation 2015. and the Challenge to Stop Smoking (Case Study of Students in Banda Aceh), vol. 10, no. 1, Journal of Communications, 2013, pp. 9-18.

Rosita R., Suswardany D.L., Abidin Z., Determinants of the Success of Quitting Smoking in Students, vol. 8, no. 1, Journal of Public Health, 2012, pp. 1-9.

Lydon D.M., Wilson S.J., Child A., Geier C.F., Adolescent Brain Maturation and Smoking: What We Know and Where We're Headed, vol. 45, Neurosci Biobehav Rev, 2014, pp. $323-42$. 